\title{
The Role of UNESCO Cultural Heritage and Cultural Sector in Tourism Development: The Case of EU Countries
}

\author{
Blanka Škrabić Perić ${ }^{1, *}$, Blanka Šimundić ${ }^{1}$, Vinko Muštra ${ }^{1}$ and Marijana Vugdelija ${ }^{2}$ \\ 1 Faculty of Economics, Business and Tourism, University of Split, 21000 Split, Croatia; blans@efst.hr (B.Š.); \\ vmustra@efst.hr (V.M.) \\ 2 International Medical, Corps, 21000 Split, Croatia; vugdelija.marijana@hotmail.com \\ * Correspondence: bskrabic@efst.hr; Tel.: +38-52-1430-778
}

\section{check for} updates

Citation: Škrabić Perić, B.; Šimundić, B.; Muštra, V.; Vugdelija, M. The Role of UNESCO Cultural Heritage and Cultural Sector in Tourism

Development: The Case of EU Countries. Sustainability 2021, 13, 5473. https://doi.org/10.3390/ su13105473

Academic Editors: Bart Neuts, João Martins, Milada Št'astná and John Martin

Received: 23 March 2021

Accepted: 11 May 2021

Published: 13 May 2021

Publisher's Note: MDPI stays neutral with regard to jurisdictional claims in published maps and institutional affiliations.

Copyright: (c) 2021 by the authors. Licensee MDPI, Basel, Switzerland. This article is an open access article distributed under the terms and conditions of the Creative Commons Attribution (CC BY) license (https:/ / creativecommons.org/licenses/by/ $4.0 /)$.

\begin{abstract}
Culture and tourism have always been related, but with blurred interpretations of the empirical relationship between those phenomena. This paper estimates the impact of different cultural indicators on tourism development in 27 EU member states for the period 2008-2018, by using dynamic panel data. The results indicate that the number of UNESCO Heritage Sites do not have a significant influence on the number of tourism overnights, whereas there are significant positive effects on international tourism receipts and tourism employment. Moreover, the additional cultural sector specifics considered in the analysis; government expenditure on culture and employment in culture, showed to have a significant positive influence on all three tourism indicators used in the research. In addition, the research results indicate that the real GDP per capita and the level of human capital are significant drivers of tourism development.
\end{abstract}

Keywords: UNESCO heritage; cultural sector; sustainable tourism development; panel data analysis; European Union

\section{Introduction}

For over seventy decades, tourism and culture have been amongst the biggest growing phenomena worldwide [1]. Tourism is considered a significant economic sector, relevant for inclusive economic growth, both globally and locally [2], and culture is recognized as a powerful driver of global sustainable development, with community-wide social, economic and environmental impacts [3]. Thus, tourism and culture present significant driving forces of economic growth and sustainable development in many destinations, with shared values and adjacent ties between tourism and culture stakeholders [4]. Culture presents a potential in the creation of place uniqueness for the tourism sector, while tourism presents a potential for reinforcing and supporting cultural production [1]. In other words, the economic impacts of tourism on culture relate to the generation of vitally important revenues and employment for cultural enterprises [5], while culture has a significant role in tourism and presents the opportunity for the improvement of special tourism products [1] Accordingly, tourism contributes to the improvement of the cultural sector's economic performance, while at the same time, culture enhances the cultural identity and branding of tourism destinations [6]. In addition, in a time of global tourism standstill due to COVID-19, culture has proven indispensable, with remarkable levels of demand reached for virtual access to museums, heritage sites, theatres, and performances [4]. Although the relationship between culture and tourism has featured enormously in theoretical research (e.g., [7]) there are limited and inconclusive understandings of this complex relation within empirical studies (e.g., [7-10]). Having all of this in mind, it is of huge importance to extend empirical studies by considering the link between tourism and culture.

The existing body of empirical literature on the relationship between tourism and culture consensually confirms the presence of synergy between the cultural and tourism sector as drivers that increase the competitiveness of a destination in the global market ([2,8-11]. 
In addition, culture is mostly perceived as the opportunity to brand unique tourism products in a destination, in order to attract higher levels of tourism demand. The studies that empirically investigate the relationship between tourism and culture focus mostly on a single country or site-specific cases, and consider few perspectives of the cultural sector (e.g., [12-15]), with different research aims and different empirical strategies applied [16]. Most empirical studies focus on cultural heritage as an attractive determinant of tourism demand, presented primarily by the number of UNESCO World Heritage Sites (WHS) (e.g., [16]). Nevertheless, those empirical studies indicate different results on the relationship between UNESCO WHS and tourism [16-20]. Romao et al. [17] offered evidence on positive effects, while Cuccia et al. [18] indicated negative effects of UNESCO WHS on the number of overnights in a destination. The most recent research, provided by [16], indicates positive effects of UNESCO WHS on international tourism arrivals. Accordingly, most existing empirical studies are focused on the relation between tourism and a specific segment of culture endowment presented by UNESCO WHS, while the empirical research dealing with the complex phenomena of culture and tourism development is highly lacking. Similar findings have been provided by [21]. They underline the importance of specific organizational and institutional aspects of the cultural sector in tourism development and suggest that the empirical research on the effects of culture on sustainable tourism development should extend beyond pure cultural heritage.

Resulting from the above presented issues, this paper contributes to the exiting empirical literature in several ways.

Firstly, by enlarging the scope of the analysis to EU 27, this paper provides new insights for identifying a general mechanism behind the relationship between different dimensions of culture and tourism on an EU level.

Secondly, the paper investigates the broader effects of culture on tourism development by employing the indicators of government expenditure on culture and cultural employment in the model, in addition to the UNESCO WHS.

Thirdly, regarding the mixed results on the influence of UNESCO WHS on tourism development, we expanded the analysis by implementing three different tourism indicators (number of overnights, international tourism receipts and employment in tourism) to embrace the demand and supply side of tourism development.

The rest of the paper is organized as follows: Section 2 provides a brief literature review, Section 3 provides the empirical model, methodology, and datasets, Section 4 gives empirical results and discussion, while Section 5 provides conclusions and recommendations for policy and further research.

\section{Literature Review}

The increased growth of international tourism demand in the last six decades has attracted the attention of empirical research settled in two strands of empirical literature, whose findings complement each other. One strand deals with the relationship between tourism and economic growth, and the other deals with the determinants of tourism demand.

The link between tourism and growth has been a subject of the large number of empirical literature. The empirical literature reveals different aspects of the relation between tourism and economic growth, from the tourism - led growth hypothesis (TLG) (e.g., [22-28]), economic-driven tourism growth hypothesis (EDTG) [29-31] to bidirectional causality or no causal relationship at all (e.g., [26,27,32-34]). Although the existing literature about the tourism-growth causal link remains mixed, those studies provide evidence on positive relation between tourism and economic growth regardless the direction of the causality.

Simultaneously with the development of this field of empirical research, the research topics on determinants of tourism demand, as well as on tourism demand modelling and forecasting, have drawn significant attention [35]. Those empirical studies aimed to recog- 
nize key factors that influence tourism demand in order to support tourism development planning and management.

Forerunner works on the determinants of tourism demand have appeared in the 1960s [36-38], and for the 1960-2014 period, Ahmed [39] reviewed the extensive number of 400 related empirical studies. The findings of existing empirical research demonstrate that the key determinants of international tourism demand are the origin country's income level, the level of the destination's development, and the relative price between destination and its source markets [35]. In addition, political stability, exchange rate, and travel costs have also been recognized as important determinants of tourism demand [40,41]. By mostly focusing on the economic, seasonal, and climate-related factors that may influence tourism demand [42], the inclusion of social and cultural factors in these analyses remained limited.

The empirical literature acknowledged the importance of the various tangible cultural heritage assets for the destination's attractiveness, while the number of UNESCO WHS have been especially in the focus of empirical research. As Graaff et al. [16] indicated, those sites have been perceived as significantly important for enhancing international tourism, especially in developed countries [43]. Romao et al. [17] confirmed the importance of UNESCO WHS among regions in Italy, France, Spain, and Portugal, based on the positive influence of UNESCO WHS on nights spent in hotels and similar establishments. Similar results are provided by [20] in the analysis of the effects of UNESCO WHS on international tourism. The authors analyzed the role of WHS among Arab countries for the 1995-2013 period and indicated that those sites are important drivers of international tourism. They especially illuminate the potential risk of a decrease in tourism inflows by $50 \%$, if the devastation of those sites occur. In addition, ref. [18] focused on Italian provinces over the 1997-2015 period, and have found a positive influence of WHS listing on the overnights, underlining the complex role of UNESCO WHS in fostering inbound tourism demand.

However, there are also opposing empirical findings to the above presented. Cuccia et al. [18] indicated that, while cultural and environmental endowments positively affected the performance of Italian tourism regions in the 1995-2010 period, the presence of UNESCO WHS sites showed contrasting effects. Moreover, focusing on UNESCO WHS within Italian municipalities, ref. [44] underlined the lack of evidence concerning the relationship between WHS and tourism attractiveness. The same authors found that the growth rates of tourism demand are not affected by WHS listings on a municipality level. In addition, reference [45] did not find significant effects of UNESCO WHS on the sustainable tourism development for European NUTS2 regions, while [21] have found no empirical evidence on the link between UNESCO WHS and employment growth. This mixed evidence might be the result of the frequent focus on two tourism indicators: overnights and international arrivals. Only a limited amount of research has investigated the relationship between employment in the tourism sector or tourism receipts and UNESCO WHS. To provide a comprehensive understanding of the role of culture on tourism development, the empirical strategy should go beyond considering UNESCO WHS as the only relevant cultural sector indicator.

Cellini and Cuccia [21] underlined that institutional aspects of cultural sector can play the positive role for growth and employment. Therefore, it is crucial to consider other cultural sector indicators as potential drivers of tourism development. Thus, we include cultural employment and government expenditure on culture as additional cultural sector indicators, to illuminate the effects of culture on tourism development.

Dwyer and Kim [46] divide factors of tourism demand in four groups: available resources (natural resources, cultural assets and heritage items), created resources (tourism infrastructure, the activities on offer, etc.), supporting factors (infrastructure in general, the quality of service, access to the destination, etc.), and destination management factors. Hence, UNESCO WHS stands for available resources, cultural employment presents created resources and government expenditure on culture stands for destination management factors. According to [8], the unique and valuable historic cores and heritage assets present 
the foundation of cultural tourism development, while created cultural resources and supporting and management factors add value to destination competitiveness.

As a result, this paper provides deeper insights into the complex phenomena of the culture and tourism relationship. More precisely, by investigating the link between three different cultural indicators and three tourism indicators, we provide valuable insights in understanding the role of culture in tourism development. Such an analysis can provide policymakers with valuable lessons for the design of culture-related policies, aiming to achieve sustainable tourism development.

\section{Data, Model and Methods}

The dataset consists of data for EU 27 member states in the period 2008-2018. The data are obtained from Eurostat, World Bank Database, and UNESCO World Heritage List. Table 1 presents variable notation, definition, expected sign and source of data.

Table 1. Variable notation, definition, explanation.

\begin{tabular}{|c|c|c|c|}
\hline Variable & Definition & Expected Sign & Source of Data \\
\hline INT_TOUR_REC & $\begin{array}{l}\text { a Real International tourism receipts } \\
\text { (in million \$) }\end{array}$ & Dependent variable & Eurostat \\
\hline OVERNIGHTS & $\begin{array}{l}\text { Nights spent (by foreign tourists) at tourist } \\
\text { accommodation establishments }\end{array}$ & Dependent variable & Eurostat \\
\hline TOUR_EMP & $\begin{array}{l}\text { Employment in the tourism sector } \\
\text { (in thousands) }\end{array}$ & Dependent variable & Eurostat \\
\hline GDPPC & ${ }^{\text {a }}$ Real GDP per capita (in \$) & + & World Bank Database \\
\hline EDU & $\begin{array}{c}\text { Educational attainment, at least completed } \\
\text { short-cycle tertiary, population } 25+\text {, total } \\
(\%) \text { (cumulative) }\end{array}$ & + & World Bank Database \\
\hline POL_STAB & $\begin{array}{l}\text { Political Stability and Absence of } \\
\text { Violence/Terrorism-WGI index }\end{array}$ & + & World Bank Database \\
\hline INF & Inflation, Consumer Prices (Annual \%) & - & World Bank Database \\
\hline UNESCO & Number of UNESCO culture heritage & $+/-$ & UNESCO \\
\hline CUL_EMP & b Cultural employment (in thousands) & + & Eurostat \\
\hline CUL_GOV_EXP & $\begin{array}{c}{ }^{\mathrm{c}} \text { Real government expenditure on culture } \\
\text { (in million Euro) }\end{array}$ & + & Eurostat \\
\hline
\end{tabular}

Notes: ${ }^{a}$ real-variable in the common currency and adjusted for inflation, ${ }^{\mathrm{b}}$ Cultural employment includes all persons working in economic activities that are deemed cultural, irrespective of whether the person is employed in a cultural occupation; ${ }^{\mathrm{c}}$ The general government expenditure on culture comprises the expenditures of all government levels (central government, state government and local government).

Our dataset consists of three dependent variables, three cultural variables, and four control variables.

The variables that depict tourism development in our model are presented via international tourism receipts, overnights, and tourism employment. According to [33,41], the most common indicator for tourism demand is the number of tourism arrivals, followed by international tourism receipts and the number of overnights. The overnights and international tourism receipts present the core indicators of tourism competitiveness [47], therefore we use OVERNIGHTS and INT_TOUR_REC as the representatives of the level of tourism development in our model.

The improvement in tourism development means that the destination is more competitive on the global tourism market. In addition, we analyze employment in the tourism sector TOUR_EMP, which presents the ability of a destination to deliver quality and competitive tourism services [47], and consequently improves tourism development. Moreover, if the tourism competitiveness is based on culture, which presents the resource for sustainable development, the sustainable tourism development should be achieved [48].

As presented in previous paragraphs, we expect mostly positive effects of the three cultural sector indicators on all the presented tourism development indicators. UNESCO stands for the number of UNESCO WHS in a destination, and as presented in previous paragraphs, even today the empirical results on the role of UNESCO WHS on tourism 
development are mixed. Hence, we expect positive and/or negative effects of UNESCO on overnights, international tourism receipts, and employment in the tourism sector. Furthermore, economic impacts generated by cultural resources are mostly related to increased value of production for local heritage sites and employment, and revenues of companies involved in tourism or other activities related to their use [49]. Still, ref. [50] argue that the concentration of protected heritage assets in space could offer large economic potential for development, but this potential depends not only on the kind of cultural goods that attract visitors the most, but also on the circumstances under which they generate the development. Those circumstances are captured in our model through data on cultural employment CUL_EMP and real government expenditures on culture CUL_GOV_EXP. The presence of the creative industry in a destination is not only connected to the presence of cultural resources, but it is the crucial sphere of culture where creativity is developed. According to [5], creativity is a key resource through which the enhancement of a competitive edge is possible. In addition, the presence of a resource, regardless of how important it may be in the cultural sense, does not inevitably mean that it will yield significant development results, if there is no convenient economic environment [51]. Therefore, CUL_EMP presents created creativity in a destination, due to a convenient economic environment that should positively affect tourism development. Finally, we expect CUL_GOV_EXP to relate positively to sustainable tourism development, since most of the existing studies analyzing effects of cultural heritage on a destination's tourism attractiveness, illuminate that the principal role should be placed towards regulatory concepts and policies relating cultural development and cultural tourism, in order to achieve sustainable tourism development [52].

The control variables, including GDPPC, EDU, POL_STAB and INFL. GDPPC, present that the inbound country's GDP. GDP p.c. is the indicator of economic development, which is the necessary prerequisite for maintaining tourism growth [53]. Accordingly, GDPPC in our model is expected to positively affect tourism development. EDU presents the educational attainment and is one of the important social indicators in a destination that should positively affect sustainable tourism development [54]. According to [55], favorable security and political stability (POL_STAB) in a destination positively affect tourism development, which is also expected to be confirmed in our model.

In the existing literature, exchange rate is often considered an important determinant of tourism [39,56] (Ahmed, 2015; Li, 2006). We decided to omit this variable for several reasons. Firstly, we have considered the problem of multicollinearity, which can arise by including exchange rate and inflation in the same regression [57]. Additionally, they indicate that inflation securely tracks the tourism and travel process, while they found that exchange rate fluctuations do not affect international tourism demand in Italy. Moreover, reference [58] found that the exchange rate has a positive, but not significant, impact on tourism arrivals for two groups of OECD countries. On the other hand, they found that inflation is statistically significant and causes a decline in the number of tourists visiting the destinations. For 208 world economies, reference [59] found that the exchange rate is not always positively related to tourism demand, while relative prices are always significant with expected negative signs in the models. Finally, since our data covers EU 27 countries, where 19 of them are the members of the EU monetary union, the exchange rates do not reveal country-specific characteristics. Therefore, inflation is a better indicator of relevant control variables in our empirical model. INFL presents the change in the price level in a destination. Its rise negatively affects a destination's competitiveness and its share in the international tourism market [60]. Therefore, we expect a negative relation between price and tourism development in our model.

Descriptive statistics for all dependent and independent variables are presented in Table 2. 
Table 2. Descriptive statistics.

\begin{tabular}{cccccc}
\hline Variable & Obs & Mean & Std. D ev. & Min & Max \\
\hline INT_TOUR_REC & 297 & $14,562.23$ & $18,162.88$ & 639 & $73,735.8$ \\
OVERNIGHTS & 267 & $4.09 \times 10^{7}$ & $6.14 \times 10^{7}$ & $1,395,899$ & $3.06 \times 10^{8}$ \\
TOUR_EMP & 270 & 7032.651 & 9382.779 & 159.5 & $41,914.5$ \\
CUL_EMP & 216 & 255.7644 & 360.3082 & 6.5 & 1689.5 \\
CUL_GOV_EXP & 189 & 2032.781 & 3385.577 & 41.9604 & $15,893.34$ \\
UNESCO & 297 & 11.40067 & 12.15876 & 0 & 49 \\
GDPPC & 297 & $31,541.17$ & $21,123.18$ & 6560.319 & $116,936.4$ \\
POL_STAB & 297 & 0.7415294 & 0.3936755 & -0.47378 & 1.512313 \\
INF & 297 & 1.775262 & 2.102663 & -4.4781 & 15.40232 \\
EDU & 231 & 25.51153 & 7.353384 & 11.09472 & 43.1259 \\
\hline
\end{tabular}

Table 3 provides pairwise correlation of different tourism indicators.

Table 3. Pairwise correlation of different tourism development indicators.

\begin{tabular}{cccc}
\hline & INT_TOUR_REC & OVERNIGHTS & TOUR_EMP \\
\hline INT_TOUR_REC & 1 & & \\
OVERNIGHTS & $0.8700 *$ & 1 & 1 \\
TOUR_EMP & $0.8458^{*}$ & $0.6007^{*}$ & 1 \\
\hline Notes: ${ }^{*}$ indicates statistical significance on $5 \%$. &
\end{tabular}

Table 3 shows that INT_TOUR_REC is strongly correlated with OVERNIGHTS and TOUR_EMP, while the correlation coefficient between TOUR_EMP and OVERNIGHTS is somewhat lower.

To detect the potential problem of multicollinearity pairwise, correlations between independent variables are reported in the Table 4.

Table 4. Pairwise correlation of control variables and cultural variables.

\begin{tabular}{|c|c|c|c|c|c|c|c|}
\hline & CUL_EMP & CUL_GOV_EXP & UNESCO & GDPPC & POL_STAB & INF & EDU \\
\hline CUL_EMP & 1 & & & & & & \\
\hline CUL_GOV_EXP & $0.8647 *$ & 1 & & & & & \\
\hline UNESCO & 0.8456 * & 0.7719 * & 1 & & & & \\
\hline GDPPC & $0.4132 *$ & 0.3513 * & $0.5369 *$ & 1 & & & \\
\hline POL_STAB & $-0.1951 *$ & -0.2318 * & $-0.4052 *$ & 0.0715 & 1 & & \\
\hline INF & -0.0261 & 0.0012 & -0.1096 & -0.0645 & -0.0286 & 1 & \\
\hline EDU & -0.0977 & 0.0203 & $-0.2337^{*}$ & 0.0711 & $0.1678 *$ & $-0.1586^{*}$ & 1 \\
\hline
\end{tabular}

Notes: * indicates statistical significance on $5 \%$.

Table 4 shows that serious problems regarding multicollinearity should not arise. A strong correlation exists only between three cultural indicators, CUL_EMP, CUL_GOV_EXP and UNESCO, but they are set individually in the different model specifications.

After the presentation of dependent and independent variables, descriptive statistics and correlation matrixes, the model of sustainable tourism development with three dependent variables, the group of control variables and three cultural variables can be written as follows:

$$
\begin{aligned}
& \text { TOUR }_{i t}=\mu+\gamma \cdot \text { TOUR }_{i, t-1}+\cdot \beta_{1} \text { GDPPC }_{i t}+\beta_{2} \text { EDU }_{i t}+\beta_{3} \cdot \text { POL_STAB } \\
& \text { it }
\end{aligned}
$$

where $T O U R_{i t}$ is the value of one of the sustainable tourism development indicators international receipts INT_TOUR_REC $C_{i t}$, overnights OVERNIGHTS ${ }_{i t}$ or tourism employment TOUR_EMP $P_{i t}$ for country $i$ in the period $t$; TOU $R_{i, t-1}$ is the value of indicator of sustainable tourism development for country $i$ in the period $t-1$. This last year's value 
of dependent variables is included because most of the relevant literature confirmed a significant impact lagged variable [23].

The notation of control variables is in the line with presented notation in Table 1. $C U L_{i t}$ is the cultural indicator UNESCO culture heritage $U N E S C O_{i t}$, real government expenditure on culture $C U L_{-} G O V_{-} E X P_{i t}$ and employment in culture $C U L_{-} E M P_{i t}$ for country $i$ in the period $t, \beta_{1}-\beta_{5}$ are parameters for estimation, $\alpha_{i}$ fixed or random effect different for each country $i$, an $\varepsilon_{i t}$ error term of the country $i$ in the period $t$ and $\mu$ is constant term.

To estimate nine model specifications which can be derived from equation (1), and according to three different indicators of sustainable tourism development and three different indicators of culture, one of the dynamic panel data estimators has to be employed in the empirical testing of the model. In recent empirical papers, differenced generalized method of moments (GMM), proposed by Arellano and Bond [61], and system GMM, proposed by Blundell and Bond [62], are most frequently used. However, system GMM is derived as an improvement of differenced GMM. It shows better properties in terms of bias and efficiency in the case of high persistence of dependent variables [63].Difference and system GMM are proposed for the data set, where the number of cross section is large, but Sotto [64] confirms good properties of system GMM in the dataset with a moderate number of cross sections, as in our dataset. Differenced GMM estimates equation (1) in the first differences, while system GMM estimates simultaneously equation (1) in levels and equation (1) in the first differences. To avoid the problem of endogeneity, which arises with the correlation between $\alpha_{i}$ and a lagged dependent variable $T O U R_{i, t-1}$, it is necessary to use instrumental variables. System GMM uses a lagged value of $T O U R_{i, t-2}$ and later lags as instrument for lagged dependent variable $\left(T O U R_{i, t-1}-T O U R_{i, t-2}\right)$ in equation in first differences, while valid instrument for lagged dependent variable $T O U R_{i, t-1}$ for equation in the levels are $\left(T O U R_{i, t-1}-T O U R_{i, t-2}\right)$ and later lags. However, this estimator allows the use of the instruments for possible endogenous variables. Accordingly, possible bidirectional relationships between tourism and growth, precisely the impacts of tourism growth on economic growth, could cause the problem of endogeneity in our model. Therefore, the possibility of controlling endogeneity by instrumental variables should be important in our model. Sotto emphasizes that the number of used instruments has to be reduced. Therefore, in all our model specifications, the number of used instruments is smaller than the number of countries, as recommended in the $[65,66]$. To avoid the possible problem of heteroscedasticity, two-step system GMM is employed in this research. This version of estimator is more efficient and robust to heteroscedasticity. A previous version of two step estimator underestimated standard errors, but Windmeijer [67] corrected it. Additionally, for nine model specifications, two diagnostics tests are conducted to confirm the validity of the estimated model. The first test is the Sargan test for the problem of endogeneity and the second test is the second order autocorrelation test AR(2) of differenced residuals.

\section{Empirical Results and Discussion}

The empirical results of the tourism sustainable development model with culture variables are presented in Tables 5-7. 
Table 5. Result of sustainable tourism development model with OVERNIGHTS as dependent variable.

\begin{tabular}{|c|c|c|c|}
\hline & $\begin{array}{c}\text { (1) } \\
\text { D.OVERNIGHTS }\end{array}$ & $\begin{array}{c}(2) \\
\text { D.OVERNIGHTS }\end{array}$ & $\begin{array}{c}\text { (3) } \\
\text { D.OVERNIGHTS }\end{array}$ \\
\hline LD.OVERNIGHTS & $\begin{array}{c}0.0704^{* * *} \\
(0.0123)\end{array}$ & $\begin{array}{l}0.376^{* * *} \\
(0.0389)\end{array}$ & $\begin{array}{l}0.147^{* * *} \\
(0.0130)\end{array}$ \\
\hline GDPPC & $\begin{array}{l}125.9 * * * \\
(7.634)\end{array}$ & $\begin{array}{c}-54.43^{* * * *} \\
(7.081)\end{array}$ & $\begin{array}{l}46.71^{* *} \\
(5.646)\end{array}$ \\
\hline POL_STAB & $\begin{array}{c}49,594.6 \\
(40,319.8)\end{array}$ & $\begin{array}{c}5794.7 \\
(53,688.3)\end{array}$ & $\begin{array}{l}64,403.8^{*} \\
(35,263.3)\end{array}$ \\
\hline INF & $\begin{array}{c}49,594.6 \\
(40,319.8)\end{array}$ & $\begin{array}{c}5794.7 \\
(53,688.3)\end{array}$ & $\begin{array}{l}64,403.8^{*} \\
(35,263.3)\end{array}$ \\
\hline EDU & $\begin{array}{c}136,038.3^{* * * *} \\
(21,633.8)\end{array}$ & $\begin{array}{l}71,213.1^{* *} \\
(36,136.7)\end{array}$ & $\begin{array}{c}139,493.4^{* * *} \\
(15,848.5)\end{array}$ \\
\hline UNESCO & $\begin{array}{c}-67,434.3^{* * *} \\
(22,972.9)\end{array}$ & & \\
\hline CUL_GOV_EXP & & $\begin{array}{c}588.6^{* * *} \\
(57.50)\end{array}$ & \\
\hline CUL_EMP & & & $\begin{array}{l}2587.8^{* * *} \\
(502.6)\end{array}$ \\
\hline _cons & $\begin{array}{c}-4,976,404.1^{* * *} \\
(343,568.3)\end{array}$ & $\begin{array}{c}-2,082,854.1^{* *} \\
(917,283.8)\end{array}$ & $\begin{array}{c}-5,161,247.7^{* * *} \\
(423,491.7)\end{array}$ \\
\hline Number of observations & 162 & 137 & 162 \\
\hline Number of countries & 27 & 25 & 27 \\
\hline Number of instruments & 20 & 19 & 20 \\
\hline Sargan test & 0.2154 & 0.2177 & 0.1363 \\
\hline AB2 test & 0.4915 & 0.4033 & 0.4848 \\
\hline
\end{tabular}

Table 6. Result of sustainable tourism development model with international RECEIPTS as dependent variable.

\begin{tabular}{|c|c|c|c|}
\hline & $\begin{array}{c}(1) \\
\text { INT_TOUR_REC }\end{array}$ & $\begin{array}{c}(2) \\
\text { INT_TOUR_REC }\end{array}$ & $\begin{array}{c}\text { (3) } \\
\text { INT_TOUR_REC }\end{array}$ \\
\hline L. INT_TOUR_REC & $\begin{array}{l}0.344^{* * *} \\
(0.0166)\end{array}$ & $\begin{array}{l}0.889^{* * *} \\
(0.0191)\end{array}$ & $\begin{array}{l}0.461^{* * *} \\
(0.0155)\end{array}$ \\
\hline GDPPC & $\begin{array}{l}0.280 * * * \\
(0.0122)\end{array}$ & $\begin{array}{l}0.187^{* * *} \\
(0.0354)\end{array}$ & $\begin{array}{l}0.382 * * * \\
(0.0336)\end{array}$ \\
\hline POL_STAB & $\begin{array}{l}6123.1 * * * \\
(477.4)\end{array}$ & $\begin{array}{c}7087.5^{* * *} \\
(645.3)\end{array}$ & $\begin{array}{c}4089.4^{* * * *} \\
(345.2)\end{array}$ \\
\hline INF & $\begin{array}{c}127.7 * * * \\
(29.95)\end{array}$ & $\begin{array}{l}-124.2 \\
(90.05)\end{array}$ & $\begin{array}{l}63.74 .^{*} \\
(37.64)\end{array}$ \\
\hline EDU & $\begin{array}{c}262.6^{* * *} \\
(33.61)\end{array}$ & $\begin{array}{c}470.0^{* *} \\
(111.4)\end{array}$ & $\begin{array}{c}161.5^{* * *} \\
(40.65)\end{array}$ \\
\hline UNESCO & $\begin{array}{c}905.0 * * * \\
(28.15)\end{array}$ & & \\
\hline CUL_GOV_EXP & & $\begin{array}{c}0.600 * * * \\
(1.172)\end{array}$ & \\
\hline CUL_EMP & & & $\begin{array}{c}25.17^{* * *} \\
(1.821)\end{array}$ \\
\hline _cons & $\begin{array}{c}-20,965.1^{* * *} \\
(1631.1)\end{array}$ & $\begin{array}{c}-23,006.9^{* * *} \\
(4124.6)\end{array}$ & $\begin{array}{c}-17,578.1^{* * *} \\
(1873.0)\end{array}$ \\
\hline Number of observations & 210 & 138 & 163 \\
\hline Number of countries & 27 & 26 & 27 \\
\hline Number of instruments & 24 & 19 & 21 \\
\hline Sargan test & 0.1348 & 0.1276 & 0.1653 \\
\hline AB2 test & 0.8144 & 0.1651 & 0.1661 \\
\hline
\end{tabular}


Table 7. Result of sustainable tourism development model with TOUR_EMP as dependent variable.

\begin{tabular}{|c|c|c|c|}
\hline & $\begin{array}{c}(1) \\
\text { D.EMP_TOUR }\end{array}$ & $\begin{array}{c}(2) \\
\text { D.EMP_TOUR }\end{array}$ & $\begin{array}{c}\text { (3) } \\
\text { D.EMP_TOUR }\end{array}$ \\
\hline L. EMP_TOUR & $\begin{array}{l}-0.0643^{* * *} \\
(0.00437)\end{array}$ & $\begin{array}{c}0.0970 * * * \\
(0.0173)\end{array}$ & $\begin{array}{c}-0.0248^{* * *} \\
(0.00540)\end{array}$ \\
\hline GDPPC & $\begin{array}{l}0.000632 \\
(0.00590)\end{array}$ & $\begin{array}{c}0.00176 \\
(0.00122)\end{array}$ & $\begin{array}{l}0.00257^{* * *} \\
(0.000849)\end{array}$ \\
\hline POL_STAB & $\begin{array}{l}4.346 \\
(10.87)\end{array}$ & $\begin{array}{c}-68.19 * * * \\
(10.78)\end{array}$ & $\begin{array}{c}-92.18^{* * *} \\
(11.21)\end{array}$ \\
\hline INF & $\begin{array}{l}1.427 \\
(0.946)\end{array}$ & $\begin{array}{l}-0.435 \\
(1.729)\end{array}$ & $\begin{array}{c}0.724 \\
(1.130)\end{array}$ \\
\hline EDU & $\begin{array}{c}6.731^{* * *} \\
(1.390)\end{array}$ & $\begin{array}{c}8.272 * * * \\
(1.978)\end{array}$ & $\begin{array}{c}6.641^{* * *} \\
(2.368)\end{array}$ \\
\hline UNESCO & $\begin{array}{c}7.799 * * * \\
(0.250)\end{array}$ & & \\
\hline CUL_GOV_EXP & & $\begin{array}{c}0.00103^{* * *} \\
(0.00231)\end{array}$ & \\
\hline CUL_EMP & & & $\begin{array}{l}0.141^{* * *} \\
(0.00887)\end{array}$ \\
\hline _cons & $\begin{array}{l}-229.7^{* * *} \\
(26.56)\end{array}$ & $\begin{array}{c}-189.8^{* * *} \\
(48.57)\end{array}$ & $\begin{array}{c}-163.1^{* * *} \\
(59.73)\end{array}$ \\
\hline Number of observations & 163 & 138 & 163 \\
\hline Number of countries & 27 & 26 & 27 \\
\hline Number of instruments & 20 & 19 & 20 \\
\hline Sargan test & 0.4551 & 0.4003 & 0.5588 \\
\hline AB2 test & 0.7220 & 0.9153 & 0.7870 \\
\hline
\end{tabular}

Diagnostics tests, the Sargan test, and the AB2 test, confirm the validity of all specified models presented from Table 4 to Tables 5 and 6 . Therefore, possible bidirectional relationship between tourism growth indicator and GDP per capita does not cause the serious problem of endogeneity. Additionally, the number of used instruments in each model is smaller than the number of cross sections. The dependent variables OVERNIGHTS and EMP_TOUR are used in the first differences because model specifications in the level did not satisfy the stationarity condition.

From Tables 4-6, the following results can be summarized. GDPPC has a positive and statistically significant influence on all three indicators of tourism in most model specifications. These results underline that higher levels of economic activity can be a stimulus for tourism activity by attracting business travelers, but also for fostering an economic environment that proliferates tourism growth, embedded in the EDTG hypothesis (e.g., $[29,30,68,69])$.

Additionally, tertiary education is also significant for all three indicators of tourism. The significant and positive influence of education in all our models reflects the robust and important role of human capital in tourism development. Thus, they confirm, firstly, that the higher levels of education enchase innovative potential, work effectiveness and efficiency, which secondly, lead to increased customer value and tourism growth [70,71].

Inflation showed to have a significant positive influence only on international receipts, while for two other considered indicators the results are not robust. Inflation changes sign and statistical significance. Our results suggest that inflation does not have a significant influence on the number of overnights and employment in tourism. This might be the result of relatively low levels of inflation among analyzed EU 27 member states which, consequently, has an insignificant influence on the lowering of purchasing power and tourism overnights in the analyzed countries.

Political stability has a positive and statistically significant influence on the number of overnights and international receipts and is in line with substantial literature that illustrates the importance of political attributes for tourism (e.g., [55,72]). 
On the other hand, political stability mostly has a significant negative influence on tourism employment. This might remind us that tourism employment is affected by different elements of the institutional environment that go beyond the political stability index coverage. More precisely, tourism employment might be driven not only by political stability, but also by other institutional framework characteristics, such as the rule of law or corruption [73].

Results revealed that UNESCO WHS have a negative influence on the number of overnights. This might represent the fact that tentative list's UNESCO WHS are also important, and not only already listed UNESCO WHS [74]. It could also reflect the scale of the tourism-enhancing effect, which is affected by the number of sites and diminishing marginal effect $[74,75]$ or even varied incentives for branding UNESCO WHS [76]. Finally, it could also represent a lack of efficient and coordinate activities on the supply and demand side of tourism actors [18]. More precisely, tourism agents may overestimate the role of UNESCO WHS and oversupply tourism capacity and services. As a result, it may have a negative influence on tourists attracted by UNESCO WHS, as they expect a complete cultural and creative experience [77] therefore resulting in a decrease in the number of overnights [18].

On the other hand, the presence of UNESCO WHS has a positive and statistically significant effect on international receipts and tourism employment. These results require special attention and an effective policy that should fully exploit the potential of heritage valorization that goes beyond the overnights lens. It has to consider the full complexity of tourism phenomena, especially effects on the structure and magnitude of tourism consumption and employment.

Moreover, mixed results might also reflect the fact that Europe possess cultural endowment, important for fostering tourism activity that goes beyond UNESCO WHS. Thus, by introducing two additional indicators (government expenditure for culture and employment in culture) we have been able to capture broader channels of culture influence on tourism. Both cultural sector indicators, government expenditure on culture and employment in culture, have positive and statistically significant impacts on all of the three tourism indicators. These results deliver the evidence that available resources (UNESCO WHS), created resources (cultural employment), and culture destination management (government expenditure on culture) are important factors of tourism development. Our empirical evidence indicate the relevance of considering a broader scope of the cultural sector when sustainable tourism is considered. Hence, the results present the missing part of the culture-tourism relation puzzle and broadens the related understanding by lessening the limitations of existing studies, which focus only on UNESCO WHS $[7,78]$.

Our results illuminate that a well-organized (developed) culture sector, with strong government financial support, is a favorable environment for overall tourism development. The results are in line with recommendations derived from Cellini and Cuccia [21] that organizational and institutional aspects of the culture sector can play a positive role for economic resilience, while we found empirical evidence for its positive role in tourism development.

\section{Conclusions}

Our research gives a broader vision about the link between culture and tourism development for EU 27 countries in the 2008-2018 period. We consider tourism through three indicators: overnights, international tourism receipts, and tourism employment. Moreover, we have presented the three dimensions of culture in a destination via available resources, created resources, and destination management factors, presented by UNESCO WHS, cultural employment, and real government expenditure on culture.

Our first contribution to the existing empirical research is illumination of the UNESCO WHS' role in tourism development. Our results reveal that UNESCO WHS have no significant effects on overnights, whereas there are significant positive effects on international tourism receipts and tourism employment. Those issues reflect the importance of prestigious, tangible cultural heritage for the destination's competitiveness and tourism de- 
velopment level. The results reveal that cultural employment and government expenditure on culture has a significant positive effect on all three indicators of tourism development. Those results underline the importance of considering the research, which deals with the role of culture on tourism development and considers the broader aspects of the cultural sector, not only a specific type of tangible cultural heritage. More precisely, it reminds us that culture includes numerous tangible and intangible cultural aspects that should be embraced for sustainable tourism development modeling.

Additionally, by confirming the positive influence of GDP per capita and educational attainment on sustainable tourism development, we underline the importance of other development drivers. We have found that a destination's development level and human capital facilitates the impacts of the cultural sector on tourism demand and employment. Therefore, to avoid stagnation and ensure sustainable development in the future, it is necessary to consider human capital as an important driver for enhancing the potential of culture and tourism in the overall development and well-being of a destination.

Finally, the importance of such findings are accentuated when the planning processes of sustainable tourism development are in focus. Since cultural heritage and created cultural resources present comparative advantages of a destination, while government expenditure on culture presents one of the elements of a competitive advantage of a destination, we conclude that without the developed governance of culture and cultural sector within a destination, the comparative advantages of a destination are not fully exploited, and the competitiveness of a destination is outranked.

As a final point, for further research it would be crucial to find a specific approach in considering the role of other forms of tangible and intangible cultural resources in tourism development, especially on a local and regional level. Furthermore, enlightening the structure and mechanism design of created resources and destination management factors, would allow us to fully observe synergies between culture and sustainable tourism, as well as to develop policies that will result in a more resilient tourism destination.

Author Contributions: Conceptualization, B.Š.P., B.Š. and V.M.; methodology, B.Š.P.; software, B.Š.P.; validation, B.Š.P., B.Š. and V.M.; formal analysis, B.Š.P. and M.V.; investigation, B.Š.P., B.Š. and V.M.; resources: B.Š.P., B.Š. and V.M.; data curation, M.V.; writing—original draft preparation, B.Š.P., B.Š and V.M.; writing-B.Š. and V.M.; visualization, M.V.; supervision, B.Š.P., B.Š. and V.M.; project administration, B.Š.P., B.Š. and V.M.; funding acquisition, B.Š.P., B.Š. and V.M. All authors have read and agreed to the published version of the manuscript.

Funding: This article is based on research conducted in the context of the SmartCulTour project that has received funding from the Euro-pean Union's Horizon 2020 Research and Innovation Programme under grant agreement no. 870708 . The authors of the article are solely responsible for the information, denominations and opinions contained in it, which do not necessarily express the point of view of all the project partners and do not commit them.

Institutional Review Board Statement: Not applicable.

Informed Consent Statement: Not applicable.

Data Availability Statement: https://www.researchgate.net/publication/351518025_Dataset_for_a rticle_Skrabic_Peric_B_Simundic_B_Mustra_V_Vugdelija_M_The_Role_of_UNESCO_Cultural_Her itage_and_Cultural_Sector_in_Tourism_Development_The_Case_of_EU_Countries_Sustainability_2 021/ citations (accessed on 22 March 2021).

Acknowledgments: The authors are grateful to Bart Neuts, the guest editor of the special issue of Sustainability under title: A European Perspective on Cultural Heritage as a Driver for Sustainable Development and Regional Resilience. Support from Lidija Petrić is also acknowledged.

Conflicts of Interest: The authors declare no conflict of interest. 


\section{References}

1. De Brito, P.M.; Ferreira, A.M.; Costa, C. Tourism and Third Sector Organisations—Strangers or Partners? Tour. Plan. Dev. 2011, 8, 87-100. [CrossRef]

2. OECD Tourism Trends and Policies 2020; OECD Publishing: Paris, France, 2020; ISBN 978-92-64-80633-7. [CrossRef]

3. UNESCO Culture Enables and Drives Development. United Nations Educational, Scientific and Cultural Organization. Available online: http:/ / www.unesco.org/new/en/culture/themes/culture-and-development/the-future-we-want-the-role-of-cultur e/culture-enables-and-drives-development/ (accessed on 22 March 2021).

4. World Tourism Organization. UNWTO Inclusive Recovery Guide-Sociocultural Impacts of Covid-19, Issue 2: Cultural Tourism; World Tourism Organization (UNWTO), Ed.; World Tourism Organization (UNWTO): Madrid, Spain, 2021; ISBN 978-92-844-2257-9.

5. Ginsburgh, V.; Throsby, D. Handbook of the Economics of Art and Culture; Elsevier: Amsterdam, The Netherlands, 2006 ; Volume 1.

6. World Tourism Organization. Recomendaciones Sobre El Desarrollo Sostenible Del Turismo Indígena; World Tourism Organization (UNWTO), Ed.; World Tourism Organization (UNWTO): Madrid, Spain, 2020; ISBN 978-92-844-2187-9.

7. Richards, G. Cultural Tourism: A Review of Recent Research and Trends. J. Hosp. Tour. Manag. 2018, 36, 12-21. [CrossRef]

8. OECD. The Impact of Culture on Tourism; OECD Publishing: Paris, France, 2009.

9. Richards, G. Cultural Tourism in Europe; Cab International: Wallingford, UK, 1994; pp. 99-115.

10. Richards, G. Tourism Attraction Systems: Exploring Cultural Behavior. Ann. Tour. Res. 2002, 29, 1048-1064. [CrossRef]

11. EC Cultural Tourism. Available online: https://ec.europa.eu/growth/sectors/tourism/offer/cultural_en (accessed on 15 March 2021).

12. Yang, C.-H.; Lin, H.-L.; Han, C.-C. Analysis of International Tourist Arrivals in China: The Role of World Heritage Sites. Tour Manag. 2010, 31, 827-837. [CrossRef] [PubMed]

13. Faber, B.; Gaubert, C. Tourism and Economic Development: Evidence from Mexico's Coastline. Am. Econ. Rev. 2019, 109, 2245-2293. [CrossRef]

14. Artal-Tur, A.; Briones-Peñalver, A.J.; Villena-Navarro, M. Tourism, Cultural Activities and Sustainability in the Spanish Mediterranean Regions: A Probit Approach. Tour. Amp Manag. Stud. 2018, 14, 7-18. [CrossRef]

15. Mura, L.; Kajzar, P. Small Businesses in Cultural Tourism in a Central European Country. J. Tour. Serv. 2019, 10, 40-54. [CrossRef]

16. Panzera, E.; de Graaff, T.; de Groot, H.L.F. European Cultural Heritage and Tourism Flows: The Magnetic Role of Superstar World Heritage Sites. Pap. Reg. Sci. 2021, 100, 101-122. [CrossRef]

17. Romão, J.; Guerreiro, J.; Rodrigues, P. Regional Tourism Development: Culture, Nature, Life Cycle and Attractiveness. Curr. Issues Tour. 2013, 16, 517-534. [CrossRef]

18. Cuccia, T.; Guccio, C.; Rizzo, I. The Effects of UNESCO World Heritage List Inscription on Tourism Destinations Performance in Italian Regions. Econ. Model. 2016, 53, 494-508. [CrossRef]

19. Rasoolimanesh, S.M.; Ringle, C.M.; Jaafar, M.; Ramayah, T. Urban vs. Rural Destinations: Residents' Perceptions, Community Participation and Support for Tourism Development. Tour. Manag. 2017, 60, 147-158. [CrossRef]

20. Groizard, J.L.; Santana-Gallego, M. The Destruction of Cultural Heritage and International Tourism: The Case of the Arab Countries. J. Cult. Herit. 2018, 33, 285-292. [CrossRef]

21. Cellini, R.; Cuccia, T. Do Behaviours in Cultural Markets Affect Economic Resilience? An Analysis of Italian Regions. Eur. Plan. Stud. 2019, 27, 784-801. [CrossRef]

22. Brida, J.G.; Cortes-Jimenez, I.; Pulina, M. Has the Tourism-Led Growth Hypothesis Been Validated? A Literature Review. Curr. Issues Tour. 2016, 19, 394-430. [CrossRef]

23. Kuliš, Z.; Šimundić, B.; Pivčević, S. The Analysis of Tourism and Economic Growth Relationship in Central and Eastern European Countries. Econ. Finance Bus. Southeast. Cent. Eur. 2018, 537-551. [CrossRef]

24. Pablo-Romero, M.d.P.; Molina, J.A. Tourism and Economic Growth: A Review of Empirical Literature. Tour. Manag. Perspect. 2013, 8, 28-41. [CrossRef]

25. Schubert, S.F.; Brida, J.G.; Risso, W.A. The Impacts of International Tourism Demand on Economic Growth of Small Economies Dependent on Tourism. Tour. Manag. 2011, 32, 377-385. [CrossRef]

26. Enilov, M.; Wang, Y. Tourism and Economic Growth: Multi-Country Evidence from Mixed-Frequency Granger Causality Tests. Tour. Econ. 2021. [CrossRef]

27. Cárdenas-García, P.J.; Sánchez-Rivero, M.; Pulido-Fernández, J.I. Does Tourism Growth Influence Economic Development? J. Travel Res. 2015, 54, 206-221. [CrossRef]

28. Balaguer, J.; Cantavella-Jordá, M. Tourism as a Long-Run Economic Growth Factor: The Spanish Case. Appl. Econ. 2002, 34, 877-884. [CrossRef]

29. Antonakakis, N.; Dragouni, M.; Filis, G. How Strong Is the Linkage between Tourism and Economic Growth in Europe? Econ. Model. 2015, 44, 142-155. [CrossRef]

30. Eugenio-Martin, J.L.; Martín-Morales, N.; Sinclair, M.T. The Role of Economic Development in Tourism Demand. Tour. Econ. 2008, 14, 673-690. [CrossRef]

31. Oh, C.-O. The Contribution of Tourism Development to Economic Growth in the Korean Economy. Tour. Manag. 2005, 26, 39-44. [CrossRef]

32. Antonakakis, N.; Dragouni, M.; Filis, G. Tourism and Growth: The Times They Are a-Changing. Ann. Tour. Res. 2015, 50, 165-169. [CrossRef] 
33. Liu, H.; Song, H. New Evidence of Dynamic Links between Tourism and Economic Growth Based on Mixed-Frequency Granger Causality Tests. J. Travel Res. 2017, 57, 899-907. [CrossRef]

34. Pulido-Fernández, J.I.; Cárdenas-García, P.J. Analyzing the Bidirectional Relationship between Tourism Growth and Economic Development. J. Travel Res. 2020, 60, 583-602. [CrossRef]

35. Song, H.; Qiu, R.T.R.; Park, J. A Review of Research on Tourism Demand Forecasting: Launching the Annals of Tourism Research Curated Collection on Tourism Demand Forecasting. Ann. Tour. Res. 2019, 75, 338-362. [CrossRef]

36. Guthrie, H.W. Demand for Tourists' Goods and Services in a World Market. Pap. Reg. Sci. Assoc. 1961, 7, 159-175. [CrossRef]

37. Gerakis, A.S. Effects of Exchange-Rate Devaluations and Revaluations on Receipts from Tourism. Eff. Exch.-Rate Devaluations Revaluations Receipts Tour. 1965, XII, 365-384. [CrossRef]

38. Gray, H.P. The Demand for International Travel by the United States and Canada. Int. Econ. Rev. 1966, 7, 83-92. [CrossRef]

39. Ahmed, D.Y.A. Analytical Review of Tourism Demand Studies from 1960 to 2014. Int. J. Sci. Res. 2015, 4, $2421-2427$.

40. Naudé, W.; Saayman, A. Determinants of Tourist Arrivals in Africa: A Panel Data Regression Analysis. Tour. Econ. 2005, 11, 365-391. [CrossRef]

41. Webber, A.G. Exchange Rate Volatility and Cointegration in Tourism Demand. J. Travel Res. 2001, 39, 398-405. [CrossRef]

42. Wu, D.C.; Song, H.; Shen, S. New Developments in Tourism and Hotel Demand Modeling and Forecasting. Int. J. Contemp. Hosp. Manag. 2017, 29, 507-529. [CrossRef]

43. Nguyen, C.P.; Binh, P.T.; Su, T.D. Capital Investment in Tourism: A Global Investigation. Tour. Plan. Dev. 2020, 1-27. [CrossRef]

44. Ribaudo, G.; Figini, P. The Puzzle of Tourism Demand at Destinations Hosting UNESCO World Heritage Sites: An Analysis of Tourism Flows for Italy. J. Travel Res. 2017, 56, 521-542. [CrossRef]

45. Romão, J.; Guerreiro, J.; Rodrigues, P.M.M. Territory and Sustainable Tourism Development: A Space-Time Analysis on European Regions. Region 2017, 4, 1-17. [CrossRef]

46. Dwyer, L.; Kim, C. Destination Competitiveness: Determinants and Indicators. Curr. Issues Tour. 2003, 6, 369-414. [CrossRef]

47. Dupeyras, A.; MacCallum, N. Indicators for Measuring Competitiveness in Tourism: A Guidance Document; OECD Tourism Papers, 2013/2; OECD Publishing: Paris, France, 2013. [CrossRef]

48. EC towards an Integrated Approach to Cultural Heritage for Europe. Available online: https://www.europarl.europa.eu/doceo /document/TA-8-2015-0293_EN.html (accessed on 21 March 2021).

49. ESPON HERITAGE-The Material Cultural Heritage as a Strategic Territorial Development Resource: Mapping Impacts Through a Set of Common European Socio-Economic Indicators. Available online: https:/ / www.espon.eu/cultural-heritage (accessed on 21 March 2021).

50. Bille, T.; Schulze, G. Culture in Urban and Regional Development; Elsevier: Amsterdam, The Netherlands, 2006; pp. 1051-1099.

51. Plaza, B. On Some Challenges and Conditions for the Guggenheim Museum Bilbao to Be an Effective Economic Re-Activator. Int. J. Urban Reg. Res. 2008, 32, 506-517. [CrossRef]

52. Cooke, P.; Lazzeretti, L. Creative Cities, Cultural Clusters and Local Economic Development; Edward Elgar Publishing: Cheltenham, $\mathrm{UK}, 2007$.

53. Adamou, A.; Clerides, S. Prospects and Limits of Tourism-Led Growth: The International Evidence; Social Science Research Network: Rochester, NY, USA, 2009.

54. Eugenio-Martin, J.L.; Martín Morales, N.; Scarpa, R. Tourism and Economic Growth in Latin American Countries: A Panel Data Approach; Social Science Research Network: Rochester, NY, USA, 2004.

55. Neumayer, E. The Impact of Political Violence on Tourism: Dynamic Cross-National Estimation. J. Confl. Resolut. 2004, 48, 259-281. [CrossRef]

56. Lim, C. A Survey of Tourism Demand Modelling Practice: Issues and Implications. In International Handbook on the Economics of Tourism; Edward Elgar Publishing: Cheltenham, UK, 2006.

57. Quadri, D.L.; Zheng, T. A Revisit to the Impact of Exchange Rates on Tourism Demand: The Case of Italy. J. Hosp. Financ. Manag. 2010, 18, 47-60. [CrossRef]

58. Athari, S.A.; Alola, U.V.; Ghasemi, M.; Alola, A.A. The (Un)Sticky Role of Exchange and Inflation Rate in Tourism Development: Insight from the Low and High Political Risk Destinations. Curr. Issues Tour. 2020, 1-16. [CrossRef]

59. Gan, Y. An Empirical Analysis of the Influence of Exchange Rate and Prices on Tourism Demand. Ph.D. Thesis, Universitiy of Lisbon, Lisbon, Portugal, 2015.

60. Lim, C. Review of International Tourism Demand Models. Ann. Tour. Res. 1997, 24, 835-849. [CrossRef]

61. Arellano, M.; Bond, S. Some Tests of Specification for Panel Data: Monte Carlo Evidence and an Application to Employment Equations. Rev. Econ. Stud. 1991, 58, 277-297. [CrossRef]

62. Blundell, R.; Bond, S. Initial Conditions and Moment Restrictions in Dynamic Panel Data Models. J. Econom. 1998, 87, 115-143. [CrossRef]

63. Blundell, R.; Bond, S.; Windmeijer, F. Estimation in dynamic panel data models: Improving on the performance of the standard GMM estimator. In Nonstationary Panels, Panel Cointegration, and Dynamic Panels; Baltagi, B.H., Thomas, B., Fomby, R., Hill, C., Eds.; Advances in Econometrics; Emerald Group Publishing Limited: Bingley, UK, 2001; Volume 1, pp. 53-91.

64. Soto, M. System GMM Estimation with a Small Sample; Barcelona GSE Working Paper: 395; Graduate School of Economics: Barcelona, Spain, 2009.

65. Roodman, D. How to Do Xtabond2: An Introduction to Difference and System GMM in Stata. Stata J. 2009, 9, 86-136. [CrossRef] 
66. Roodman, D. A Note on the Theme of Too Many Instruments. Oxf. Bull. Econ. Stat. 2009, 71, 135-158. [CrossRef]

67. Windmeijer, F. A Finite Sample Correction for the Variance of Linear Efficient Two-Step GMM Estimators. J. Econom. 2005, 126, 25-51. [CrossRef]

68. Alhowaish, A.K. Is Tourism Development a Sustainable Economic Growth Strategy in the Long Run? Evidence from GCC Countries. Sustainability 2016, 8, 605. [CrossRef]

69. Lin, V.S.; Yang, Y.; Li, G. Where Can Tourism-Led Growth and Economy-Driven Tourism Growth Occur? J. Travel Res. 2018, 58, 760-773. [CrossRef]

70. Assaf, A.G.; Josiassen, A. Identifying and Ranking the Determinants of Tourism Performance: A Global Investigation. J. Travel Res. 2011, 51, 388-399. [CrossRef]

71. Milovanović, V. The Impact of Human Capital on Tourism Development. TISC-Tour. Int. Sci. Conf. Vrnjač. Banja 2017, 2, 54-72.

72. Llorca-Viverot, R. Terrorism and International Tourism: New Evidence. Def. Peace Econ. 2008, 19, 169-188. [CrossRef]

73. Khan, M.A.; Popp, J.; Talib, M.N.A.; Lakner, Z.; Khan, M.A.; Oláh, J. Asymmetric Impact of Institutional Quality on Tourism Inflows Among Selected Asian Pacific Countries. Sustainability 2020, 12, 1223. [CrossRef]

74. Bak, S.; Min, C.-K.; Roh, T.-S. Impacts of UNESCO-Listed Tangible and Intangible Heritages on Tourism. J. Travel Tour. Mark. 2019, 36, 917-927. [CrossRef]

75. Su, Y.-W.; Lin, H.-L. Analysis of International Tourist Arrivals Worldwide: The Role of World Heritage Sites. Tour. Manag. 2014, 40, 46-58. [CrossRef]

76. Wuepper, D.; Patry, M. The World Heritage List: Which Sites Promote the Brand? A Big Data Spatial Econometrics Approach. J. Cult. Econ. 2017, 41, 1-21. [CrossRef]

77. Richards, G. Creativity and Tourism: The State of the Art. Ann. Tour. Res. 2011, 38, 1225-1253. [CrossRef]

78. Boniface, P. Managing Quality Cultural Tourism; Routledge: London, NY, USA, 1995; ISBN 9780203424230. 